Migration, Ethno-nationalist Destinations, and Social Divisions:

Non-Jewish Immigrants in Israel

For Ethnopolitics 9:3, 2010

\title{
David Bartram
}

\author{
Department of Sociology \\ University of Leicester \\ University Road \\ Leicester LE1 7RH \\ England \\ t: +44116252 2724 \\ f: +441162525259 \\ d.bartram@le.ac.uk
}




\title{
Migration, Ethno-nationalist Destinations, and Social Divisions: \\ Non-Jewish Immigrants in Israel
}

\begin{abstract}
:
Immigrants in ethno-nationalist destinations encounter difficulties of integration particularly to the extent that they lack shared ethnicity with natives. But an analysis of non-Jewish immigrants in Israel shows that lacking shared ethnicity is by no means an insurmountable obstacle to integration, even in strongly ethno-nationalist destinations. Non-Jewish immigrants - even those who entered as migrant workers - have achieved a certain degree of membership in Israeli society. Moreover, their presence has exacerbated certain divisions among Jewish Israelis. Even in ethno-nationalist destinations, then, the immigration of non-co-ethnics does not result only/inevitably in divisions between immigrants and natives: it can also divide natives, while some immigrants and natives find a measure of common ground.
\end{abstract}


Migration to ethno-nationalist states presents opportunities for simplistic thinking about possibilities for integration for both co-ethnics and non-co-ethnics. This paper explores ideas about migration to Israel, in particular, and argues for a more thoroughgoing rejection of the terms of home-grown Israeli discourse as a path towards better understanding of that migration. The critique offered here is focused on the notion that non-Jewish immigrants have very limited possibilities for integration in Israeli society. ${ }^{1}$ When immigrants are not Jewish and not otherwise eligible under the Law of Return, it sometimes appears difficult for observers to include them in the category of immigrants at all; the large numbers of Thais, Romanians, Filipinas, etc. who have migrated to Israel in the last two decades are, in both official discourse and some social science analysis, merely 'foreign workers' or 'labour migrants' and as such not 'immigrants' with any real possibility of being or becoming Israelis.

The discourse underlying Israel's migration regime is of course highly consequential: those who enter under the Law of Return have extensive rights and social acceptance, and those who come as migrant workers encounter a set of practices and attitudes that have the expected exclusionary effects. But the difference between the two groups is often overstated, and a core argument of this paper is that both groups must be analyzed in terms common to the analysis of migration everywhere.

The terms relevant here relate to possibilities and prospects for integration, particularly when immigrants lack shared ethnicity with natives. The strong ethno-national character of Israel does make it difficult for non-Jewish immigrants to become integrated into Israeli society. But immigrants everywhere can encounter obstacles to integration including natives' beliefs that they simply 'don't belong' (even countries like the US and Canada are only partial exceptions in this regard) - and yet sometimes accomplish a degree of integration even in difficult contexts. A difference between ethno-national contexts and liberal or multicultural contexts is indeed a difference. But it is not an absolute difference, and even in ethno-national contexts immigrants - including those who lack shared ethnicity

\footnotetext{
${ }^{1}$ There is a corollary proposition: Jewish immigrants, with immediate full/formal citizenship, achieve integration with little or no difficulty. The inadequacy of this idea is well understood among those who study migration to Israel (and equivalent 'return' migrations elsewhere): even co-ethnics often encounter exclusion and stratification (e.g. Ben-Rafael 1982).
} 
- are often able to achieve a significant degree of social membership. Migration, especially of non-co-ethnics to ethno-nationalist destinations, is easily imagined as highly divisive, particularly in ethnic terms. But even in ethno-national contexts such migration is not only divisive: immigrants in such societies encounter 'contexts of reception' (Portes and Rumbaut 1996) that contain elements facilitating their partial inclusion (as well as elements resulting in partial exclusion).

Another core argument in this paper, then, is that, as against mainstream Zionist discourse and the practices of the Israeli state drawing on that discourse, some non-Jewish immigrants entering as 'foreign workers' are in the process of becoming Israeli. One important factor facilitating this process is the more or less simultaneous immigration of non-Jews from the former Soviet Union, who were eligible under the Law of Return by virtue of having close Jewish relatives. State policies and social attitudes facilitating integration of non-Jewish 'Russians' enhance possibilities for integration of other non-Jews as well. Both groups also continue to experience varying degrees of exclusion. But the Israeli government has not stopped the inflows of people in either group, nor has it succeeded in its declared aim of minimizing the migrant worker population (e.g. via forced deportation), and even the migrant workers are developing new forms of identity that partially overlap with the identities of natives - which also leads natives to redefine their own identities in particular ways.

The result is a transformation of the social divisions of Israeli society that includes processes of finding commonality across ethnic lines, not just exacerbation of divisions. To the extent that immigration of non-Jews has been divisive, that process has included aggravation of divisions among Jews, not merely division between Jews and non-Jews. In both respects, the consequences of non-Jewish immigration to Israel (commonality across ethnic lines, divisions among natives) are contrary to what one might anticipate in relation to non-co-ethnic migration to ethno-nationalist states.

The paper proceeds in the next section with a brief overview of Jewish immigration to Israel in the first several decades of its existence as an independent country. It then turns to the experiences of Russian and Ethiopian immigrants, with particular attention to the significant components of non-Jews in those inflows (also giving consideration to doubts 
about Jewishness for both groups as a whole). The appearance of non-Jews in immigration under the Law of Return is a significant development, raising difficult questions about personal status and inter-ethnic relations. These issues are even more salient and problematic in relation to Israel's relatively new population of guestworkers, discussed in the subsequent section. Israeli political elites have generally embraced the notion that Israel will succeed in avoiding the long-term settlement of guestworkers (as against experience in several European countries), but some 'guestworkers' are already showing signs of such settlement. The penultimate section considers the experiences of the different groups in light of common-sense expectations about non-co-ethnic immigration. ${ }^{2}$

\section{'Traditional' Immigration to Israel}

Immigration to Israel is sometimes considered to be different from the kind of immigration that most other countries experience. Jews who reside elsewhere live in the 'Diaspora'; the Hebrew term - 'galut', meaning exile - carries even stronger connotations of not being where one belongs. A number of ideas embedded in language used regularly by many Jews - in Hebrew but also in other languages - reinforce the notion that living outside Israel is for Jews an anomaly, to be corrected by return to the homeland. Jews are strangers everywhere else - and the core premise of traditional Zionism is that this is exactly the problem that the creation of a Jewish state was designed to resolve. The 'uniqueness' of Israel in this regard is often overstated (Shuval 1998) - but it is worth exploring briefly, so that we can appreciate how recent migration waves are different in some central ways.

As Joppke argues (2005), the practice of selecting immigrants by ethnicity is on the decline in liberal states (though there are variations in the strength of that trend). Historically, it was taken for granted, a matter of common sense, that 'sovereignty' entitled a nation-state to reproduce and 'shape' its population through immigration policies that used both numerical restrictions and explicit ethnic preferences. The very idea of a nationstate seemed to demand attention to such matters, and even leaving aside the obvious

\footnotetext{
${ }^{2}$ This paper does not deal with the place of non-Jewish immigrants in relation to Israel's Arab population. The term 'non-Jewish immigration' could be taken to include the movement of Palestinians from the West Bank and Gaza to Israel via marriage to Israeli citizens, which in the postOslo period amounted to an estimated 30,000 persons (Rebhun and Malach 2009). I am not aware of any scholarly research on this migration stream. For more general analysis of Arab/Palestinian ethnicity in Israel, see e.g. Jamal 2007 and Rouhana 1997.
} 
instances of cultural imperialism embodied in policies such as 'White Australia', it was not unusual to find claims that it was legitimate to give preference to potential immigrants who are 'like us' in ostensibly important ways. ${ }^{3}$ In contrast, immigration policies in many liberal states today strive for a greater degree of 'universality' and 'neutrality', giving weight to 'achieved' over 'ascribed' characteristics - e.g. economically desirable skills, in keeping with a neo-liberal market-oriented set of assumptions.

But Israel is a clear exception: a central aspect of its identity as a (or the) Jewish state is the notion that it belongs to Jews everywhere, that they are already part of the IsraeliJewish 'nation'. ${ }^{4}$ The best illustration of the point is the Law of Return, the primary piece of legislation that authorizes and structures immigration to Israel. A key feature is that the Law of Return gives no consideration whatsoever to economic characteristics of the (prospective) immigrant or other factors such as age or educational level (Cohen 2009). ${ }^{5}$ The only factor that matters is Jewishness: if one is Jewish (or has close Jewish family), one belongs in Israel and can enter freely, gaining citizenship immediately upon entry. The notion that one can 'return' is hardly unique: many citizens of one country residing in another can return to the former at any point. But the Law of Return extends this principle across generations, indeed across many centuries, so that it applies to people - non-citizens - whose distant ancestors might once have lived in the territory today called Israel.

Some key Hebrew words and Jewish concepts reinforce the point. For many years the Hebrew word for migration ('hagirah') was not used, especially to describe immigrants entering under the Law of Return (Shuval 1998). Instead the preferred term is 'aliyah', literally meaning ascent. That word has deep religious connotations, entirely positive/ valorised ones. In synagogue services that include readings from the Torah, a member of

\footnotetext{
${ }^{3}$ Walzer 1983 offers a relatively recent defence of this idea.

${ }^{4}$ This point is central to those who argue that Israel is therefore not really a liberal democracy but instead an 'ethnic democracy' (Smooha 1990) or an 'ethnocracy' (e.g. Ghanem et al. 1998; cf. Gavison 1999 for a rebuttal).

${ }^{5}$ In the early 1950s some Israeli elites wanted limitations on the entry of people in categories considered undesirable, even if Jewish - but restrictions of this type were not implemented (Hacohen 2003). On the other hand, such concerns did apparently contribute to a studied passivity in relation to Ethiopian Jews, who were not actively encouraged to move to Israel until the $1980 \mathrm{~s}$ (Kaplan and Salamon 2004).
} 
the congregation can be invited for - and honoured by - an 'aliyah': one ascends to the raised platform on which the Torah reading takes place and recites blessings before and after the reading itself. The word also applied to the pilgrimages required of Jews while the Temple was still standing: passages from the Torah instructed that during certain festivals (Sukkot, Passover and Shavuot), one would 'ascend' to Jerusalem for the Temple service.

To describe Jewish migration to Israel as aliyah, then, is to approve of it at a fundamental level - as indeed most Israeli Jews do. Likewise the word used for emigration 'yerida', meaning descent - for many years had a negative connotation in equal measure (Shuval and Leshem 1998). The late prime minister Yitzhak Rabin once described emigrants in terms that were translated variously into English as 'the lowliest of parasites' and 'gutless scum'. In more recent years there is less inclination to use such denigrating language - but one of the reasons for the change has to do with the desire to convince emigrants to come back to Israel, ${ }^{6}$ a goal that many Israelis understand might be better accomplished if one avoids insulting them (Cohen 2007).

These elements combine to produce the claim that Jewish migration to Israel is hardly migration at all, in the normal sense of the term. The defining characteristic of immigrants in most contexts is that they are foreign, and their presence is thus an anomaly that demands resolution (e.g. through departure, or perhaps naturalization). International migration is not simply geographical relocation (Castles and Miller 2009); instead, its most salient feature is that it involves, at least potentially, a change of national membership, entailing a number of transformations at the individual level that would be associated with change in nationality. But insofar as Israel is the 'Jewish state', Jews everywhere are already imagined to be part of the Israeli 'nation'. Following Anderson (1983), this act of 'imagining' is powerful: the word confirms their membership rather than denoting its emptiness. As against the experience of many other societies, migration to Israel is thus not itself an anomaly but the resolution of an anomaly - the 'ingathering of the exiles', to use the religious term. It hardly makes sense then to describe them as foreign - and entirely

\footnotetext{
${ }^{6}$ The size of this population depends on definitions and is perhaps half a million, mostly in the 'Jews and others' category (but including also roughly 100,000 Arab Israelis) (Cohen 2009). At roughly $8 \%$ of the Israeli Jewish population in Israel (Avineri et al. 2009), emigration on this scale is considered a serious loss and a failure of Zionism.
} 
sensible to grant them citizenship immediately upon arrival, with no waiting period or conditionality. Other countries have had laws similar to the Law of Return - Germany is an important example - and other countries also give priority to co-ethnics in deciding whom to admit. But the Israeli case is the most extreme, to the point that it is sometimes taken to be difficult to analyze in the terms used for other cases.

This, at any rate, is how things appear from a mainstream Zionist perspective. And a key implication is that immigration in Israel is not a cause of social division but rather of social (re)unification, a making whole rather than a making of divisions. Again, the main distinctive characteristic of immigrants in general is their non-belonging to the nation: in a word, they are different, in ways that are held to really matter. But Jewish immigrants to Israel are held not to be different in the ways that really matter and are therefore not really immigrants in the normal sense.

However: other ways have in practice mattered greatly, even if some Zionist discourse about Jewish immigrants has sometimes created a tendency to exaggerate the importance of co-ethnicity and downplay other dimensions of difference and other processes apart from 'return' and inclusion. Jewish immigration to Israel is distinctive in ways that are worth giving proper attention, but Jewish immigration to Israel is not somehow 'aliyah' instead of immigration (Shuval 1998).

As an instance of migration, then, Jewish immigration has simultaneously created (or deepened) a number of significant social divisions and effected a partial reunification of the 'Jewish people' as intended. Outside of Israel, being Jewish is in part a matter of ethnicity (also of religion, with a complex articulation between the two), ${ }^{7}$ typically understood as a single ethnicity. In Israel, however, Jewishness is subject to ethnic divisions. Traditionally, the core division was between Ashkenazi and Mizrachi Jews. Its salience had much to do with the articulation between ethnicity and other forms of stratification, particularly economic and political, i.e., the fact that in general Ashkenazi Jews held higher economic

\footnotetext{
${ }^{7}$ The ethnic dimension of Jewishness is captured, quite controversially, in a recent decision by a British court of appeal holding that an Orthodox Jewish school had practised racial/ethnic discrimination in failing to accept a boy on the grounds that his mother is not Jewish according to Orthodox definitions, thus neither is he - despite the fact that he attends synagogue regularly and observes Jewish law/practices to a high level (Butt 2009).
} 
and political positions (e.g. Swirsky 1989, Kahane 1986). Mizrachi disadvantage was reinforced by their Arab cultural background, in a context that delegitimized Arab culture (Yiftachel and Ghanem 2004) and (partly as a consequence) sought to 'absorb' them in classic 'melting-pot' fashion (Cohen-Almagor 1995), an attempt resisted by many of them (Ben-Rafael 2007).

One must not overstate the extent of division between Mizrachi and Ashkenazi Jews in Israel in the days of mass Mizrachi immigration (1940s and 1950s). ${ }^{8}$ Despite experiencing mistreatment, prejudice, exclusion, etc., the fact that Mizrachi Jews were after all Jews contributed to a sense of national belonging. Many Ashkenazim did in fact often treat Mizrachim as inferior - but virtually no one (among Ashkenazi Jews) took the view that they did not genuinely belong in Israel. The point is partly formal: they entered the country as full citizens. But this dimension of membership was not merely formal: Mizrachi immigrants, despite being foreign-born, were not 'foreign' in terms of nationality. The Palestinian citizens of Israel, despite being native-born, were arguably more foreign than the Mizrachim in the schema of Israeli national identity and citizenship (Shachar 2000).

Nor is the mere fact of being an immigrant sufficient to discern strong differentiation between Mizrachi Jews and Ashkenazi Jews in this period. Most Ashkenazim were also immigrants, or the sons and daughters of immigrants. Being an immigrant in 1950s Israel was common, even a core element of Israeli identity; very few Israeli Jews had no migration history in living memory. The onset of Zionist immigration is generally dated to the $1880 \mathrm{~s}$, at which point the Jewish population of Palestine was roughly 30,000 (Schölch 1985). When Israel became an independent country in 1948 , the Jewish population was 700,000 - and most of these people were, necessarily, immigrants.

We thus encounter instances of Jewish immigration that add complexity to the notion that in ethno-national contexts social divisions result primarily from immigration of non-co-ethnics. In accordance with Zionist ideology, Jewish migration to Israel during this earlier period can reasonably be described as a reunification in the Jewish homeland, wherein Jews were welcomed without the high degree of antipathy and rejection that often

\footnotetext{
${ }^{8}$ Mizrachi immigration did not begin only in the 1940s: there were earlier (smaller) waves of immigration of Jews from Yemen, for example (Shafir 1989).
} 
characterizes the experience of immigrants elsewhere. But despite the fact of co-ethnicity and their eligibility for automatic citizenship, some immigrants (particularly the Mizrachim) experienced a certain degree of antipathy and rejection. As is widely understood, the resulting social divisions were very significant and persist into the present, ${ }^{9}$ though there have also been trends of convergence (Ya'ar 2005, Benski 1994).

\section{Russian and Ethiopian Immigrants}

If even Jewish immigrants to Israel experience a certain degree of exclusion, it is not hard to imagine that non-Jewish immigrants (or Jewish immigrants whose Jewishness is considered by some to be in doubt) would encounter greater difficulties. That expectation is borne out in the experience of Russian ${ }^{10}$ immigrants who entered Israel beginning in 1989 and Ethiopians arriving mainly in 1985-86 and 1991. Most immigrants in both groups are Jewish, but a significant number particularly of the Russians are not, i.e., they are not recognized as Jewish by Israel's rabbinic authorities. But even the non-Jewish immigrants have achieved a significant degree of integration in Israel, despite a traditional Zionist understanding of 'aliyah' that contemplates only Jewish immigration. Non-Jews have encountered certain difficulties in Israel, but their experience belies the notion that non-co-ethnic immigrants in ethno-national contexts will find only restricted prospects for integration.

An earlier wave of Russian migration to Israel, in the 1970s, had characteristics similar to those of other Jewish immigration influxes, and Russians in this wave largely assimilated into the Ashkenazi segment of the Israeli Jewish population. But the more recent Russian immigration has had a very different character, for three reasons. One is sheer size: since 1989, Russian immigration has added more than one million people to Israel's population, and they now constitute more than $13 \%$ of the total - a very large/rapid migration inflow by any historical standard. Secondly, the state did not impose strong expectations of 'absorption' (assimilation) on the Russians (as had been done with the

\footnotetext{
${ }^{9}$ Witness the stunning success of a political party - Shas - capitalizing on resentment concerning Mizrachi disadvantage (Peled 2001).

${ }^{10}$ Some so-called 'Russians' come from other countries in the former Soviet Union (e.g. Ukraine, Georgia), and some writers use 'FSU' to describe the entire group. However, 'Russians' is commonly used in Israel, and it makes sense at least insofar as even those from other countries typically speak Russian.
} 
Mizrahim): it was considered acceptable for them to retain core elements of the cultural baggage they brought with them (Ben-Rafael 2007). The other central fact is the significant component of non-Jews in this group, roughly 300,000 who are not Jewish according to the strict Orthodox (matrilineal) definition. The Law of Return, as amended in 1970, extends rights of immigration and citizenship to anyone with a Jewish grandparent or spouse, even if the migrant is not Jewish by Orthodox religious standards (see e.g. Shachar 2000). ${ }^{11}$ As noted above, the Law of Return was intended to facilitate Jewish immigration, on the basis that Jewishness endowed the immigrants with a high degree of national belonging - but in recent years it has also enabled the immigration of large numbers people who are not Jewish in consequential ways (i.e., recognized as such by religious authorities).

These three factors have placed certain limits on the extent to which Russian immigrants have become Israeli, i.e., in regard to their own sense of identity and the way their identity is perceived by veteran Israelis. Being 'Russian' has become a new Israeli ethnicity, one that doesn't dissolve into the traditional Ashkenazi/Mizrachi divide even for those who are Jewish by religious law and might otherwise be considered Ashkenazi (Al-Haj 2004). Many Russians give higher priority to their Russian and Jewish elements of identity (over Israeli), and (halakhic) Jews and non-Jews are not terribly different in this regard (BenRefael and Peres 2005). Russians in Israel have built a substantial infrastructure that sustains elements of Russian identity and culture: newspapers, grocery stores (some of which openly sell pork), cultural institutions, etc. Many Russians consider it important to transmit their Russian identity to their children, particularly via maintenance of Russian language. There is also a relatively high degree of residential segregation and a separate political party (Herzog 2009).

Those who lack recognition as Jewish encounter additional obstacles to integration. One particular problem relates to marriage. Jewish religious authorities exercise formal control over matters of personal status (marriage, divorce, burial, etc.; Muslim religious authorities control such matters for the Muslim population - see Merin 2004), and there is no provision for civil marriage. Those who are not recognized as Jewish (but are also not

\footnotetext{
${ }^{11}$ The Reform Jewish practice of recognizing patrilineal descent, common in the USA, is not well established in Israel, except for purposes of the Law of Return.
} 
members of other religions) therefore find it impossible to get married at all in Israel. An alternative is to get married abroad and then register the marriage with the Interior Ministry, and some people travel to Cyprus for that purpose. But doing so is not inexpensive, and many couples choose simply to cohabit (with a certain degree of legal recognition upon registration). The problem is self-perpetuating, as the offspring of nonJewish mothers will themselves be barred from getting married in Israel.

Issues relating to marriage also affect Jewish Russian immigrants. The fact that so many Russians are not recognized as Jewish leads some Israelis to adopt rejectionist attitudes towards all Russians. In the minds of ultra-Orthodox Jews, being Russian is itself now grounds for suspicion regarding Jewish bona fides - so that Russians are in general not considered suitable marriage partners. One mechanism enabling ultra-Orthodox people to act on this preference is lists compiled by rabbinic authorities who determine (to their satisfaction) whether someone is or is not Jewish. The various lists of eligible marriage partners are necessarily incomplete, and a marriage can proceed if one can satisfy the rabbis (via production of documents or testimony of witnesses) that one is indeed Jewish though succeeding in this process can be extremely difficult. ${ }^{12}$ But the aim in producing lists is to eliminate uncertainty, to obviate the need for determination: after all, if a couple have decided to get married and only then set out to establish their eligibility, from their point of view it is too late. If a very religious person has any reason to doubt the Jewishness of a potential partner, checking a list before getting involved can prevent heartache and shame. Because of widespread doubts about the Jewishness of Russians, there is a much greater likelihood that they will not be included on the lists.

But even the fact of non-Jewishness is not an insurmountable obstacle to a significant degree of integration into Israeli society for Russian immigrants. It is important not to overstate the difference between Jewish and non-Jewish Russians in this regard. Many of those who count unequivocally as Jewish do not have a well-developed sense of Jewish religious identity and knowledge, particularly as religious education and practice were discouraged by the Soviet authorities (Ben-Refael and Peres 2005). On the other side, many of those who are not Jewish by Orthodox rules nonetheless consider themselves Jews

\footnotetext{
${ }^{12}$ As evident in a long story in the New York Times Magazine (Gorenberg 2008).
} 
- in part because of their Jewish family connections (again, the basis of their eligibility under the Law of Return). There is also the fact that they were treated as Jewish by authorities in the Soviet Union (which, along with similar Nazi practice in Germany, helps explain the logic of extending the right of return to those with Jewish family connections).

The identification of non-Jewish Russians with the larger Israeli Jewish population is reinforced in some significant institutional ways. Once in Israel, they are 'converted' into Israeli Jews not in a religious sense but sociologically, i.e., socialized particularly by the educational system and the army (Cohen 2009). ${ }^{13}$ Additionally, official Israeli data, e.g. published by the Central Bureau of Statistics, use population categories that appear at first to work in strange ways: in particular, the major division is between 'Jews and others' and Arabs. One might expect to find instead a major division between 'Jews' and 'others'. One explanation for this counterintuitive practice is to be found partly in the politics of Israeli demography, where the Arab/Palestinian part of the population is considered by many to constitute a threat to Israel's identity as a 'Jewish state'. To counter that threat, official data include 'others' such as non-Jewish Russians in the 'Jewish' category, thus diminishing the weight of the Arab category; Lustick observes on this basis that Israel is less a 'Jewish state' than a 'non-Arab' state (1999). While Jewish religious authorities adopt a highly exclusionary stance towards non-Jewish Russians, the Israeli state is keen to 'absorb' them into Israeli Jewish nationality and thus offers them all the rights and support granted to any immigrant eligible under the Law of Return.

Similar points can be made about immigrants to Israel from Ethiopia, who arrived mainly in two 'waves', in 1985-86 and 1991 and now number roughly 100,000, including the second generation (Ben-Eliezer 2008). Ethiopians in Israel have encountered a significant degree of rejection by some other Israelis and in certain respects are poorly integrated, as evident in high rates of poverty and unemployment, residential segregation, etc. (Offer 2004, Kaplan and Salamon 2004). A significant obstacle to integration is doubts about their

\footnotetext{
${ }^{13}$ The issue of religious conversion to Judaism among Russians is quite complex. In brief, possibilities for religious conversion are extremely limited, and many of the conversions for Russians that did take place were revoked in 2008 (Hacker 2009). The rabbinic establishment sets extremely stringent demands, and in any event most Russians are secular by outlook and practice and are not interested in adopting Orthodox (or ultra-Orthodox) ways. Various government initiatives to increase rates of conversion for immigrants have all ended in failure (Sheleg 2004, 2009).
} 
Jewishness. The Sephardi Chief Rabbi in the 1970s (Ovadia Yosef) had determined that the 'Beta Israel' were Jewish - thus making them eligible under the Law of Return. But by the time they arrived the attitude among religious authorities had changed, and they were required to undergo a symbolic process of conversion (via immersion in a mikveh, a small pool of water) (Wagaw 1993) - which however has not been sufficient to alleviate doubts in the minds of many, especially among the ultra-Orthodox. In other respects attitudes among some Israelis amount to 'cultural racism', e.g. when schools refuse to accept Ethiopian children on the pretence that the children are not prepared for the type of study provided there (Kashti et al. 2009). Some Ethiopian youths have responded by developing an oppositional identity akin to American hip-hop, intended to signal rejection of what they perceive as dominant Israeliness (Ben-Eliezer 2008). Finally, as with the Russians a certain portion of the Ethiopian Israeli population - the so-called Falashmura (or Feres Mura) have a tenuous relationship with Judaism, for having practiced Christianity in Ethiopia after their (apparently) Jewish ancestors converted, perhaps under duress (Seeman 2009).

But Ethiopian immigrants, even the Falashmura, are after all immigrants under the Law of Return and have been the object of government policy designed to incorporate (or 'absorb', from klitah) them through provisions such as subsidized housing and affirmative action in employment. Even if these policies have often failed in terms of stated objectives, they function on a symbolic level as a sign of Ethiopians' belonging on par with other immigrants, and as with other immigrants there is a consensus among Jewish Israelis (including political elites) that the Ethiopians belong in Israel (Kaplan and Salamon 2004). Instances of racism typically result in immediate and widespread public condemnation and policy reversals. Rates of army service - as noted, an important integration mechanism among Ethiopian men exceed the Israeli Jewish average. Political incorporation was evident in a 1996 demonstration in front of the prime minister's office to protest a policy of discarding donated blood on grounds that Ethiopians in general had disproportionately high HIV infection rates. The demonstration resulted in public apologies from the president and prime minister and contributed to the election of an Ethiopian Knesset (parliament) member (though it did not lead to a change in policy on donated blood) (Weil 1996).

The fact that Russian and Ethiopian immigrants have Israeli citizenship (granted immediately on entry) is also very important in grounding and signifying their high degree of 
membership in and identification with Israeli society. Having formal citizenship by no means guarantees a high degree of social membership, particularly in a context where citizenship itself is strongly ethno-national (as demonstrated in obvious ways by the situation of Arabs in Israel) (Shafir and Peled 2002). But Israeli citizenship is (at least for Jews) quite different from the 'thin' citizenship that characterizes the USA (on the latter, Heller 1997 and Joppke 1999), and admission into Israeli citizenship under the Law of Return is consequential.

The increasing component of non-Jews in migration inflows under the Law of Return is a significant development. These immigrants face some difficult problems, and from the perspective of strictly religious Jews their presence is a problem. But it must be remembered that many of these immigrants are non-Jewish in only a strict religious sense; as noted above, non-Jewish Russians undergo a 'sociological conversion' that leads to a certain degree of identification with and acceptance by many secular Israeli Jews. While that process is significant in its own right, it is also potentially relevant to the prospects for Israel's relatively new population of migrant workers.

\section{Migrant workers}

Although small numbers of non-Jews went to Israel as migrant workers in the 1970 s and 1980s, large-scale 'guestworker' migration ${ }^{14}$ began in 1993, with strong similarities to the experience of the European countries that used guestworkers several decades earlier. With extremely limited prospects for formal citizenship, migrant workers' presence in Israel might seem to carry few if any implications for Israeli identity or 'ethnoscape'. But that commonsense conclusion, though no doubt held by a large proportion of Israelis who believe that 'foreign workers' are simply and irredeemably foreign, overlooks some of the key lessons available in the history of immigrants and 'guestworkers' in other countries (e.g. Rogers 1985). Some migrant workers in Israel have put down deep roots and have begun to think of themselves as Israelis. While some government policies and popular attitudes make that perspective seem implausible, there are also important instances of policies and attitudes that ground and reinforce the development of this new identity.

\footnotetext{
${ }^{14}$ It would be misleading to offer a precise indication of the size of this population; a reasonable estimate is roughly 200,000 (Rebhun and Malach 2009). The Israeli government has very limited capacity for producing accurate data on the migrant workers (e.g. Avineri et al. 2009).
} 
Israel's experience of rapid 'guestworker' immigration can be explained with reference to several factors. The proximate cause was the closure of Israel's borders to Palestinians from the West Bank and Gaza, following several deadly suicide bombs in March 1993. Until that point, Palestinians had supplied cheap labour in the agricultural and constructions sectors, and although the intifadah had periodically disrupted the flow of this labour since 1987, the violence in Israel proper in 1993 led to an extended closure and thus to the severe interruption of production in those sectors. Employers might have responded to these events by embarking on a program of labour-saving investment (particularly as the use of rudimentary construction methods was/is widespread), but it was easier and more profitable for them to import replacement workers. The relative weakness of the Israeli state - its susceptibility to clientelist policy-making dynamics - meant that pressure on the government to this end succeeded rather quickly (Bartram 2005). There was also a significant geo-political dimension to these decisions: prime minister Yitzhak Rabin was keen to demonstrate to the Palestinians that their labour was replaceable and thus their standard of living vulnerable, in the event that the violence continued (Raijman and Kemp 2007).

The rapid growth of the migrant worker population was not solely a result of government policy in an active sense. A great many migrant workers in Israel are undocumented. In part the presence of undocumented workers is attributable to the activities of traffickers and 'manpower' companies, who can make enormous profits by charging the workers 'agency fees' (Kruger 2005). Another factor is Israel's attractiveness as a tourist/pilgrimage destination: the Israeli government finds it difficult to distinguish reliably between bona-fide tourists and those who use tourism as a means of entry for purposes of finding work (Willen 2007).

Israel thus faces an issue that has become a recurring theme in wealthy countries: the 'place' of immigrants who are 'wanted but not welcome' (Zolberg 1987). For a large proportion of the population, the answer is easy: they have no place. Large proportions of Israelis (Arabs as well as Jews) hold negative/xenophobic attitudes towards migrant workers and oppose granting them rights (Raijman and Semyonov 2004). One might also conclude that the position of the government is that migrant workers do not belong in Israel, particularly in light of a sustained deportation campaign begun in 2002 employing harsh tactics by any standard (Willen 2007, Wurgaft 2006). A long-term place for non-Jewish 
immigrant is entirely inconsistent with traditional Zionist ideology, and it is unsurprising even if slightly jarring, in light of Israel's extensive immigration history - to hear government officials state that 'Israel is not an immigration country' (senior minister in Labour and Social Affairs, quoted in Rosenhek 1999).

But the history of 'guestworkers' in Europe suggests that reality might not respect ideology, not even in Israel. That history is captured in Philip Martin's 'iron law of labor immigration: there is nothing more permanent than temporary workers' (1994: 86). The receiving society and the workers (some of them at least) tend to become addicted to one another, and while authoritarian governments are sometimes able to ensure that the 'guests' go home (Abella 1995), democratic countries are markedly less successful.

The Israeli government has issued numerous pronouncements to the effect that it intends to deport migrant workers and reduce their numbers. But certain key elements of the society do not share these goals. Employers in construction and agriculture have not altered their preference for cheap foreign labour - certainly not in the sense that they have made the investments that would help 'upgrade' those sectors and make the work (and pay) more attractive to Israeli citizens. A large number of individual citizens as well continue to want to employ migrant workers: another key market segment is the use of migrant workers (typically Filipinas and Latinas) for care of elderly relatives (Raijman et al. 2003). Many of the workers themselves want to stay permanently (Ben-Refael and Peres 2005). Under the most propitious circumstances governments often find it difficult to implement migration policies with complete or even nearly complete effectiveness, and the circumstances surrounding migrant workers in Israel are decidedly not propitious.

Above all, the government's own actions simply do not support the notion that it has 'decided' to get rid of the migrant workers. Quotas for employment permits in the key sectors are regularly renewed, leading to accusations that the government operates a 'revolving door' policy (offering new permits despite deporting people), with 'manpower' companies as the main beneficiaries (Kruger 2005). ${ }^{15}$ It has failed to regulate the manpower companies and other employers in ways that implement existing laws, never mind passing

\footnotetext{
${ }^{15}$ A HaAretz headline in October 2009 read: "Ignoring Arab women, ministry okays 3,000 new foreign workers" (Weiler-Polak 2009b).
} 
laws that would constrain their activities effectively (Dahan and Gill 2006, Pilovsky 1999). One of the earliest scholarly publications on migrant workers in Israel described the policy making practice as 'overwhelmingly reactive - inadequately considered, ill-conceived, ambivalent in relation to their ultimate purpose and, in the course of implementation, vulnerable to "privatization" (Borowski and Yanay 1997, 495), and there is precious little evidence of any significant change.

The question of migrant workers' place in Israeli society in the future is therefore the wrong question. Migrant workers are present in Israel now and have been present in the aggregate for more than sixteen years, and questions relating to their place in Israeli society cannot be put off on the (dubious) grounds that at some point in the future they will be gone. It is more pertinent and revealing to describe the place of migrant workers in Israeli society in the present. A common perception is that workers encounter a high degree of exclusion and rejection. While that perception is largely accurate, it is not the entire story: despite lacking a secure legal status - in part because their lack of Jewishness means that most Israelis consider them to be entirely unsuitable for membership in Israeli society migrant workers in Israel have achieved a limited degree of integration.

The orientation/attitudes and actions of some migrant workers in Israel have much in common with those of migrant workers in numerous other destinations around the world (for a general discussion see Piore 1979). Despite an early intention to accumulate savings and return home, some immigrants (particularly those from Latin America) have decided that life in Israel is good, even in the absence of secure legal status. After satisfying debts associated with migration and securing a degree of improvement in employment, some immigrants begin to establish a more permanent and comfortable existence in Israel: acquiring better housing and consumer goods, deepening ties with native Israelis (as well as other immigrants), etc. The most significant step is family (re-)formation - arranging for their children to come to Israel, or forming new families in Israel - which makes return ‘home' much less likely (Kalir 2006).

A number of government actions and policies have the effect of 'grounding' and reinforcing migrant workers' membership in Israeli society - particularly in an expanded view of government beyond the national level to include municipal policies, especially those 
of Tel Aviv (cf. Rosenhek 2002). The most significant of these is the Tel Aviv municipality's sponsorship of an 'Aid \& Information Centre for the Foreign Community', to mediate between various government agencies and migrant workers (even the undocumented) regarding policies that affect their welfare. Though its declared aims explicitly exclude the notion of challenging the (ostensible) national policy of reducing/eliminating the migrant worker population, its activities have the impact of carving out spaces of membership and belonging (Alexander 2007). One key mechanism for this dynamic involves the recruitment of representatives from the migrant worker community, to give them a voice regarding perspectives on their needs especially in relation to health care, welfare, and children's education (Kemp and Raijman 2004). Among the unintended consequences is the creation of a community infrastructure that can be used for mobilization regarding other issues. Already the municipality provides a number of welfare services even to undocumented workers and their children - and so this 'illegal' population has achieved a degree of 'citizenship' (particularly at the level of the city - note the affinity between these words, cf. Holston 1999) in the normal Marshallian sense. Even at the national level: the 'Israeli Government Portal' (www.gov.il) contains a 'Guide for Migrant Workers' with information on rights and where to find assistance of various types.

Policy relating to pregnancy/childbirth and children is particularly consequential in both the short and long term. As noted above, demography is a highly politicized topic in Israel, and it is not hard to find statements by politicians that demonstrate awareness of the long-term consequences associated with the birth and education of 'foreign' children on Israeli soil. In 2000 Interior Minister Eli Yishai (from the religious Shas party) told the Knesset: 'They have to be deported before they become pregnant' (quoted in Kemp 2007, 679). And an official statement from the Ministry of the Interior from the late 1990s read in part: 'When the foreign children study Israel's heritage in our schools, we make them feel that they are part of us. It would be better if those children would not go to school and would watch TV all day instead' (quoted in Rosenhek 2002). And yet Israeli schools do accept the children of migrant workers, regardless of parents' legal status (particularly in Tel Aviv), and some even adopt a policy of multiculturalism in dealing with 'foreign' children (Resnik 2009). A similar contradiction between declared national policy and implementation at the local level is found in the provision of government-sponsored 
reproductive services for pregnant women regardless of legal status - despite the ostensible threat to 'demographic security' posed by foreign children (Willen 2005).

The next logical step is citizenship for children born to migrant workers - and indeed this step has been taken, albeit a small one. There is no jus solis tradition of citizenship in Israel, and possibilities for non-Jews to gain Israeli citizenship have always been very narrow, limited in most circumstances to marriage. ${ }^{16}$ But a government decision in 2005 created provisions for naturalization for a small number of children under restricted conditions (including minimum age, competence in Hebrew, and enrolment in school) (Kemp 2007). After their children become citizens, the parents themselves are granted permanent residence. The government declared that this was to be a one-time offer, applying only to people already living in the country, and the numbers of applications approved was very low, approximately 1500 as of mid-2007 (Ilan and Azouly 2007). But the initial requirements were loosened (the minimum age lowered from ten to six, and the requirement that the parents had to have entered the country legally - e.g. not as fake tourists - was abandoned), and the notion that it will only happen once is not very plausible. The justification offered by proponents was familiar: these children think of themselves as Israeli, do not know any other country, and are not fluent in any other language (apart from Hebrew). These conditions are unlikely to change.

The conclusion to be drawn from these developments is that a variety of non-Jews (who are also not Palestinian) from a very diverse range of backgrounds (Ecuadorian, Nigerian, Filipino, etc.) are, in limited and specific ways, becoming Israelis. The limits are of course significant. Kemp et al. (2000) apply the term 'margizens' (from Martiniello 1992) to denote their position on the margins of Israeli society; they are not even 'denizens'. But the

\footnotetext{
${ }^{16}$ A policy change in 1995 rendered non-Jewish spouses of Jewish Israeli citizens ineligible under the Law of Return and imposed a waiting time and other requirements for naturalization (Hacker 2009). Additionally, as of 2003 a controversial law has made it very difficult for Palestinian residents of the West Bank and Gaza to gain Israeli citizenship or residence permits via marriage to an Israeli citizen such citizens being in virtually all cases Arab (Peled 2007). This ostensibly 'temporary' law, upheld by the High Court of Justice in 2006 partly on 'security' grounds, is a blatant instance of indirect ethnic discrimination against Arab citizens of Israel and has helped revive the 'ethnocracy' debate. The demographic intent of the law - reduction of Arab population growth - is blindingly obvious, as acknowledged (and supported) by the former director of the Association for Civil Rights in Israel, Ruth Gavison, in an op-ed in HaAretz in July 2008.
} 
term 'margizen' describes not just exclusion but also a degree and form of social membership. The notion that they are not members - not at all - is manifestly false. Most migrant workers in Israel are unlikely ever to become Israeli in the sense of holding an Israeli passport. But the voluminous literature on Marshallian citizenship demonstrates that the passport one holds is typically only part of what we want to know about one's citizenship.

\section{Non-Jewish Immigrants and Ethnic Divisions}

It would be easy to imagine that there is a straightforward dichotomy between Jewish and non-Jewish immigrants to Israel, leading to a straightforward conclusion that non-Jewish immigrants (at least those lacking Jewish connections) are an anomaly and have virtually no prospects for gaining any substantial degree of membership in Israeli society. This view places too much emphasis on Jewishness in relation to migration to Israel. ${ }^{17}$ Being Jewish matters, but it is not the only issue that matters for immigrants in Israel. Immigrants draw on a variety of resources to achieve a degree of membership in the destination. At early stages, non-Jewish immigrants in an ethno-national destination such as Israel will find it virtually impossible to use shared ethnicity as a resource in this way. But to the extent that such immigrants are successful in using other resources to achieve social membership, we then find a subsequent set of processes resulting in the development of a certain degree of shared ethnicity (in addition to persisting ethnic divisions).

Given that the immigration in question has happened quite recently, any analysis in these terms is necessarily provisional: the situation is fluid, with a lack of clear boundaries and tendencies. But even that sense of vagueness is significant in relation to common ways of perceiving identity and ethnicity in Israel. From a mainstream Zionist perspective, Jewishness is the dominant element of identity, and Jewish unity is among its highest values (including the unity that comes from reunification of Jews via aliyah). Migration to Israel in recent years has further undermined the fit between ideology and reality in this regard: some Jewish Israelis feel and express solidarity with non-Jewish immigrants (even the migrant workers) as well as antipathy towards other Jews (i.e., to a greater extent than in

\footnotetext{
${ }^{17}$ It also imagines that it is possible to know, definitively, whether some is or is not Jewish. As is evident above, there are different ways of categorizing, emerging from different notions of what it means to be Jewish.
} 
the past). In other words, immigration has altered patterns of ethnic division in some surprising ways.

One arena for inter-ethnic alliances (and intra-ethnic dissension) involves the movement for civil marriage provisions, which would end the monopoly of religious authorities over matters of personal status. This control has long been a source of deep resentment by secular Jews in Israel, particularly in relation to marriage (the ceremony must be conducted by an Orthodox rabbi, irrespective of whether the individuals are members of or attend services at a synagogue). In mobilizing to create an option for civil marriage, many secular veteran Israelis are making common cause with Russian immigrants (Jewish and non-Jewish alike) against the ultra-Orthodox. The practice of travelling to Cyprus did not begin with Russian non-Jewish immigrants - secular Israelis from a variety of backgrounds have been getting married this way for many years. For those who are Jewish by Orthodox rules, doing so was a matter of personal preference - while for non-Jewish Russians there is no alternative if one is not satisfied with cohabitation and wants to get married. As Israeli journalist Alexander Yakobson (2009) points out, 'anger at the religious establishment is an important cultural marker of Israeli Jewish society. This is also a kind of integration'. The religious establishment understands the basis of its power very well and has so far prevented passage of the various bills presented in the Knesset. This movement - a key battlefield in Israel's Kulturkampf (Shain 2002) - has not succeeded yet and might ultimately fail (in the sense that people stop working for it).

But changes in law are only part of the story. As a result of non-Jewish immigration, there have been significant changes in what people do, and 'practice' is arguably more important than law for understanding ethnic divisions. The marriage issue is central in this regard, given the generally high (though also variable) degree of endogamy in ethnic groups (e.g. De Vos 2006). The unity of Jews as an ethnic group in Israel, while never complete, has declined in recent years in part through changes in marriage practices particularly in the ultra-Orthodox population. As described above, individuals in this subgroup of Jews are now presumptively unwilling to marry individuals in other sub-groups, particularly the Russians and Ethiopians, because of doubts about their Jewishness. While those concerns arise in relation to a specific dimension of religious law, that dimension has a strong ethnic character, insofar as it refers primarily to descent: one is Jewish by Orthodox 
understandings of halakha (religious law) if one's mother is Jewish (or via conversion). In addition, the rate of marriage has been declining, with some (halakhic) Jews and non-Jews alike preferring simply to cohabit rather than submit to the demands of the rabbinate. In this central dimension of personal life, then, immigrants have helped exacerbate certain divisions (religious vs. secular) while diminishing others (immigrant vs. native). If the movement for civil marriage is eventually successful, it will amount to a dramatic change in the basis of Israeli identity. Even without a legislative change, however, there have been significant and complex changes in Israeli identity resulting from the Russian and Ethiopian immigration waves.

In other words, the social division apparent in ultra-Orthodox lists of eligible marriage partners is not limited to suspicion and rejection towards Russians by the ultraOrthodox: antipathy and rejection go in the other direction as well. Many secular Israeli Jews were strongly supportive of Russian immigration and are deeply disturbed by the attitudes and actions of the ultra-Orthodox, particularly the rabbinical establishment. Dissension between religious and secular Jews predates the Russian immigration wave - but that immigration has been a significant factor aggravating the tensions. From the point of view of secular Jews, it is deeply unjust for the State of Israel to accept immigrants as 'Jewish enough' for the Law of Return - and for compulsory service in the army, in particular - but then fail to address their problems of personal status relating to central matters such as marriage. 'Veteran' secular Jews often feel that they have more in common with Russians (regardless of Jewishness in a halakhic sense) than with people in the ultraOrthodox population in this regard. One can also find resentment and distance between Russians and other secular Jews. But what bears emphasis here is that division between immigrants and natives is not the only consequence of the Russian immigration wave: that immigration wave has also exacerbated a central division between native Jewish Israelis, while immigrants and certain natives have succeeded in finding significant areas of common ground.

A similar dynamic can be discerned in the relations among the ultra-Orthodox, Ethiopian immigrants, and secular veteran Israelis. Having been cut off from the development of rabbinic Judaism in Europe and the Middle East, Ethiopians practiced a very different form of Judaism. Rabbinic authorities in Israel were unwilling to accept the 
legitimacy of such 'deviations' and (in addition to insisting on symbolic conversion) were particularly keen to enrol Ethiopian children in state religious schools so that they would learn the 'right' version. Many secular Israelis saw the demands and actions of the rabbinate as harassment (Kaplan and Salamon 2004). Perhaps to an even greater extent than with Russian immigrants, secular native Israelis and Ethiopian Jewish immigrants have found significant common ground.

The 'place' of non-Jewish migrant workers in Israel is much more tenuous. But as indicated above, there are also areas of commonality between migrant workers and the Jewish Israeli population. This is certainly the case in the perspective of some of the migrant workers themselves. Many migrant workers are Christians, ${ }^{18}$ and Israel's image as the 'Holy Land' is one reason many of these workers have chosen to find work in Israel as against some other destination. While living in Israel, some Christian workers have adopted an identity of 'Christian Zionists', believing (in common with some fundamentalist Christians in the USA) that God has indeed given Israel to the Jews. This 'identification' with a traditional Jewish Zionist perspective is then enhanced by a set of innovative religious practices: wearing kippot (skullcaps) and talitot (prayer shawls) during church services (Raijman and Kemp 2004). Extending this practice even further, some immigrants from Latin America have created and joined 'Messianic Jewish' congregations, and some have also expressed a desire to convert to Judaism (though the state and the rabbinate have effectively made this impossible for people in the 'foreign workers' category) (Kalir 2006).

It is not clear that this attempt to develop a Christian equivalent of an Israeli Jewish identity is perceived as convincing by significant numbers of Israeli Jews. It is certainly not taken seriously by the Interior Ministry (e.g. for purposes of granting legal status). But seems entirely plausible that migrant workers' attempts to 'fit in' via adoption of elements of Israeli Jewish culture (in addition to the basic accomplishment of learning Hebrew) would enhance prospects for developing ties with Israelis. Many Tel Aviv residents (i.e., Israeli citizens) embrace cosmopolitan and multicultural attitudes and reject what they perceive as the tribalism of traditional Zionism. People of this type are not troubled by the presence of non-Jews: '"I do not have any problem with the foreign workers... On Saturday you see

\footnotetext{
${ }^{18}$ The Chinese are an exception, though some have converted to Christianity in Israel (Kalir 2009).
} 
colours, it's fun to see. I feel as if I live in a city like New York"' (quoted in Fenster and Yacobi 2005, p. 206). Cosmopolitanism among Israelis arises more from increasing appetites for foreign travel and media, but in recent years it is also an effect of immigration, particularly of non-Jews (Berthomière 2003).

A variety of laws have been passed and policy proposals offered to reverse this trend. A recent proposal for reform of Israeli immigration laws considers non-Jewish immigration a disaster, both for Israelis and the immigrants themselves (Avineri et al. 2009). Laws and policies of this sort might produce their intended outcomes, at least to a degree. But one must be careful not to read reality from laws and policies. On the contrary: to a certain extent the laws and policies demonstrate the new reality, the magnitude of the 'problem' one wants to solve. One example is the 'Hadera/Gadera' rule, which stipulated that migrant workers were required to live north of Hadera (roughly 25 miles north of Tel Aviv) or south of Gadera (ten miles to the south of Tel Aviv) (Weiler-Polak 2009a). As an effort to reduce the concentration of migrant workers residing in Tel Aviv, the rule was an utter failure, and its repeal shortly after adoption in summer 2009 merely confirmed the reality abhorred by those in the Interior Ministry who concocted it and the powerlessness of government to do much about it.

Many observers, Israeli and non-Israeli alike, appear to hold strongly to the assumption that being Jewish (or, at a minimum, having close Jewish family ties) is the sine qua non for successful integration in Israel as an immigrant. Existing laws and social attitudes do create a difficult context for non-Jewish immigrants. But immigrants encounter difficult contexts in a great many destinations around the world; Israel is hardly unique in this regard, not even in having a high degree of ethnic closure to outsiders. Even in the difficult context of Israel, non-Jewish immigrants are succeeding, to a certain limited degree, in establishing new homes and new identities, in part through development of ties and affinities with native Israelis. Even immigration of the migrant workers has not resulted in a set of social divisions that draw uncrossable lines between them and the rest of the Israeli population. 


\section{Conclusion}

The overwhelming majority of the Israeli Jewish population has a migration history in the $20^{\text {th }}$ century. For those eligible to enter under the Law of Return, immigration has had some of the unifying effects envisioned by traditional Zionism (though even Jewish immigrants encountered a measure of the exclusion experienced by immigrants everywhere). Migration to Israel in the last two decades, however, has had a very significant non-Jewish component. But even immigration of non-Jews has not been only divisive in its effects. There is a tendency in popular thinking (if not in scholarly work) to believe that immigrants are almost inevitably a divisive force, in part because of widespread anti-immigrant sentiment but also because immigrants are almost inevitably different from natives in some obvious ways. But this paper has argued that, even in Israel where divisions are already extensive and a 'new' population might be expected only to exacerbate them, there are other effects to consider as well.

Ethnic relations in Israel have become extraordinarily complex in recent years (especially considering the relatively small size of the population). To summarize the changes described above in relation to recent immigration: 'Russian' is a new Israeli ethnicity, and while many Russians are Jewish, some are not, and yet even the non-Jews in the Russian group are fully Israeli. A similar pattern describes the smaller group of Ethiopians, whose acceptance as Jews is sometimes compromised by racist attitudes among some other Israelis. The migrant workers (by definition, non-Jewish) are barely accepted as 'immigrants', let alone potential full members (citizens) of Israeli society - and yet their position as 'margizens' constitutes a certain degree of membership in addition to exclusion, and a small number have been granted a path towards permanent status (even citizenship, in the case of some children). And among natives the presence of the non-Jewish immigrants has exacerbated divisions between certain groups of Jews - mainly, the secular and the ultra-Orthodox - particularly as people in each group deeply resent the attitudes and behaviour of some in the other group towards the non-Jews (or, in the case of the ultraOrthodox, even towards other Jews).

As Kimmerling (2001) asserts, there is not a unified notion of 'Israeliness', even among Israeli Jews; Ben-Rafael speaks of a 'multiplication of divergences' (2007, p. 68). 
Israeli ethnicity was never as simple as some might assume, with a straightforward division between Jews and Arabs denoting a set of (internally) undifferentiated identities and social processes. Instead, there were always internal divisions in both groups (e.g. Kop and Litan 2002), and those divisions involved a significant degree of stratification and oppression. The process of creating the Israeli nation-state produced profound changes in the (pre-state) identity of both groups, and that process was strongly marked by interaction between the two main groups (Jewish and Arab) as well (Kimmerling 2008). There have also long been significant structural and affective ties between Jewish and Arab Israelis and certain groups of foreigners (Diaspora Jewry and other Arabs, respectively). But until the early 1990s, the ethnic landscape of Israel was characterized by a high degree of exclusivity in relation to those two main categories: Israelis were either Arab or Jewish, with little relevance for other ethnic categories. The immigration of non-co-ethnics (i.e., mainly non-Jews) has profoundly transformed that landscape - not merely through the presence of the immigrants themselves but through their effect on the identity and interactions of natives.

Israel is by no means the only highly ethno-nationalist destination country that struggles with the immigration of non-co-ethnics. Migration to Japan, consisting of Nikkeijin and prototypical 'guestworkers' (see e.g. Surak 2008), evinces some key similarities to Israel. But there are some important differences as well, particularly insofar as it is considered extremely difficult for foreigners to become Japanese (Lee et al. 2006, Tsuda and Wagatsuma 2006). The Japanese case helps reveal the relative accessibility of Israel to nonco-ethnic immigrants. One reason for that relative openness is that the Jewish core of Israeli identity contains an important disjuncture between its religious and social/ethnic elements. If non-Jewish Russians can become Jewish (not just Israeli) in an ethnic sense via a 'sociological conversion' while lacking recognized religious status, then it becomes difficult to see what would prevent a similar process for other non-Jewish immigrants. Most Israelis do not want to see migrant workers integrated into Israeli society in this way - and while this fact is consequential, comparisons to other cases of immigration (including the contrasting case of Japan) suggest that it will be insufficient to prevent at least some migrant workers from becoming Israeli to a significant degree. 


\section{References}

Abella, M. (1995) Asian migrant and contract workers in the Middle East, in: R. Cohen (ed), The Cambridge survey of world migration, pp. 418-423 (Cambridge: Cambridge University Press).

Al-Haj, M. (2004) Immigration and ethnic formation in a deeply divided society: the case of the 1990s immigrants from the Former Soviet Union in Israel (Boston: Brill).

Alexander, M. (2007) Local migrant policies in a guestworker regime: the case of Tel Aviv, in: S.S. Willen (ed), Transnational Migration to Israel in Global Comparative Context, pp. 73-86 (Plymouth: Lexington Books).

Anderson, B. (1983) Imagined Communities: Reflections on the Origin and Spread of Nationalism (London: Verso).

Avineri, S., Orgad, L. and Rubinstein, A. (2009) Managing global migration: a strategy for immigration policy in Israel (Jerusalem: Merkaz Metzilah, in Hebrew).

Bartram, D. (2005) International labor migration: foreign workers and public policy (New York: Palgrave Macmillan).

Ben-Eliezer, U. (2008) Multicultural society and everyday cultural racism: second generation of Ethiopian Jews in Israel's 'crisis of modernization', Ethnic and Racial Studies, 31(5), pp. 935961.

Ben-Rafael, E. (1982) The Emergence of Ethnicity: Cultural Groups and Social Conflict in Israel (Westport: Greenwood Press).

Ben-Rafael, E. (2007) Mizrahi and Russian Challenges to Israel's Dominant Culture: Divergences and Convergences, Israel Studies, 12(3), pp. 68-91.

Ben-Rafael, E. and Peres, Y. (2005) Is Israel One? Religion, Nationalism, and Multiculturalism Confounded (Leiden: Brill).

Benski, T. (1994) Ethnic Convergence Processes under Conditions of Persisting SocioeconomicDecreasing Cultural Differences: The Case of Israeli Society, International Migration Review, 28(2), pp. 256-280.

Berthomière, W. (2003) L'émergence d'une Tel Aviv cosmopolite ou les effets d'un fin mélange entre reconfigurations sociopolitiques internes et externes, Cahiers de la Méditerranée, 67.

Borowski, A. and Yanai, U. (1997) Temporary and illegal labor migration: the Israeli experience, International Migration, 35(4), pp. 495-509.

Butt, R. (2009) Jewish schools to admit pupils on religion, not race, after high court ruling, The Guardian, 31 July.

Castles, S. and Miller, M.J. (2009) The age of migration (London: Macmillan Press).

Cohen-Almagor, R. (1995) Cultural pluralism and the Israeli nation-building ideology, International Journal of Middle Eastern Studies, 27(4), pp. 461-484.

Cohen, N. (2007) From overt rejection to enthusiastic embracement: changing state discourses on Israeli emigration, GeoJournal, 68(2-3), pp. 267-728.

Cohen, Y. (2009) Migration Patterns to and from Israel, Contemporary Jewry, 29(2), pp. 115-125.

Dahan, Y. and Gill, A. (2006) Between Neo-Liberalism and Ethno-Nationalism: The Policy and Law of Deporting Migrant Workers, Mishpat u'Mimshal, 10(1), pp. 347-385 (in Hebrew). 
De Vos, G. (2006) Ethnic pluralism: conflict and accommodation, in: L. Romanucci-Ross, G.A. De Vos, and T. Tsuda (eds), Ethnic identity: problems and prospects for the twenty-first century, pp. 1-36 (Lanham: AltaMira Press).

De Vos, G. and Wagatsuma, H. (2006) Cultural identity and minority status in Japan, in: G. De Vos, L. Romanucci-Ross, and T. Tsuda (eds), Ethnic Identity: Problems and Prospects for the Twentyfirst Century, pp. 119-156 (Lanham: Altamira Press).

Fenster, T. and Yacobi, H. (2005) Whose city is it? On urban planning and local knowledge in globalizing Tel Aviv-Jaffa, Planning Theory and Practice, 6(2), pp. 191-211.

Gavison, R. (1999) A rejoinder to the 'ethnic democracy' debate, Israel Studies, 4(1), pp. 44-72.

Gavison, R. (2008) Civic Equality Does Not Mean Freedom of Immigration, HaAretz, 14 July.

Ghanem, A., Rouhana, N. and Yiftachel, O. (1998) Questioning 'Ethnic Democracy': A response to Sammy Smooha, Israel Studies, 3(2), pp. 253-267.

Gorenberg, G. (2008) How Do You Prove You're a Jew?, New York Times, 2 March.

Hacker, D. (2009) Inter-Religious Marriages in Israel: Gendered Implications for Conversion, Children, and Citizenship, Israel Studies, 14(2), pp. 178-197.

Hacohen, D. (2003) Immigrants in Turmoil: Mass Immigration to Israel and its Repercussions in the 1950s and After (Syracuse: Syracuse University Press).

Heller, T. (1997) Modernity, Membership, and Multiculturalism, Stanford Humanities Review, 5(2).

Herzog, S. (2009) Ethnic and immigrant residential concentration, and crime rates, Journal of Criminal Justice, 37(5), pp. 427-434.

Holston, J. (1999) Cities and citizenship (Durham: Duke University Press).

Ilan, S. and Azouly, Y. (2007) Foreign workers' kids: 1,500 to stay, 800 to go, HaAretz, 20 June.

Jamal, A. (2007) Nationalizing States and the Constitution of 'Hollow Citizenship': Israel and its Palestinian Citizens, Ethnopolitics, 6(4), pp. 471-493.

Joppke, C. (1999) How immigration is changing citizenship: a comparative view, Ethnic and Racial Studies, 22(4), pp. 629-652.

Joppke, C. (2005) Selecting by origin: ethnic migration in the liberal state (Cambridge: Harvard University Press).

Joppke, C. and Morawska, E. (2003) Integrating Immigrants in Liberal Nation-States: Policies and Practices, in: C. Joppke and E. Morawska (eds), Toward assimilation and citizenship: immigrants in liberal nation-states, pp. 1-36 (Basingstoke: Palgrave Macmillan).

Kahane, R. (1986) Informal agencies of socialization and the integration of immigrant youth into society: an example from Israel, International Migration Review, 20(1), pp. 21-39.

Kalir, B. (2006) Christian Aliens in The Jewish State: Undocumented Migrants from Latin America Striving for Practical National Belonging in Israel (PhD Thesis: University of Amsterdam).

Kalir, B. (2009) Finding Jesus in the Holy Land and Taking Him to China: Chinese Temporary Migrant Workers in Israel Converting to Evangelical Christianity, Sociology of Religion, 70(2), pp. 130156.

Kaplan, S. and Salamon, H. (2004) Ethiopian Jews in Israel: a part of the people or apart from the people?, in: U. Rebhun and C. Waxman (eds), Jews in Israel: contemporary social and cultural patterns, pp. 118-148 (Hanover: Brandeis University Press/University Press of New England). 
Kashti, O., Ettinger, Y. and Weiler-Polak, D. (2009) Petah Tikva schools ordered to take in Ethiopian students, HaAretz, 2 September.

Kemp, A. (2007) Managing Migration, Reprioritizing National Citizenship: Undocumented Migrant Workers' Children and Policy Reforms in Israel, Theoretical Inquiries in Law, 8(2), Article 12.

Kemp, A. and Raijman, R. (2004) 'Tel Aviv is not foreign to you: urban incorporation policy on labor migrants in Israel, International Migration Review, 38(1), pp. 26-51.

Kemp, A., Raijman, R., Resnik, J. and Schammah Gesser, S. (2000) Contesting the limits of political participation: Latinos and Black African migrant workers in Israel, Ethnic and Racial Studies, 23(1), pp. 94-119.

Kimmerling, B. (2001) The invention and decline of Israeliness: state, society, and the military (Berkeley: University of California Press).

Kimmerling, B. (2008) Clash of Identities: Explorations in Israeli and Palestinian Societies (New York: Columbia University Press).

Kop, Y. and Litan, R.E. (2002) Sticking together: the Israeli experiment in pluralism (Washington DC: Brookings Institution).

Kruger, M. (2005) Strangers in a strange land: international migration in Israel, Global Migration Perspectives (Global Commission on International Migration).

Lee, S.i., Murphy-Shigematsu, S. and Befu, H. (2006) Japan's Diversity Dilemmas: Ethnicity, Citizenship, and Education (Bloomington: iUniverse).

Lustick, I. (1999) Israel as a non-Arab state: the political implications of mass immigration of nonJews, Middle East Journal, 53(3), pp. 101-117.

Martiniello, M. (1992) Leadership et pouvoir dans les communautés d'origine immigrée (Paris: L'Harmattan).

Merin, Y. (2004) The Right to Family Life and Civil Marriage under International Law and Its Implementation in the State of Israel, bepress Legal Series, \#275.

Peled, Y. (ed) (2001) Shas - the challenge of Israeliness (Tel Aviv: Yediot Ahronot, in Hebrew).

Peled, Y. (2007) Citizenship Betrayed: Israel's Emerging Immigration and Citizenship Regime, Theoretical Inquiries in Law, 8(2), Article 10.

Pilovsky, L. (1999) 'Present absentees': the functioning of manpower organizations in dealing with foreign workers in Israel, and their connections with government institutions, in: R. Natanson and L. Achdut (eds), The new laborers: workers from foreign countries in Israel, pp. 41-89 (Tel Aviv: HaKibbutz HaMeuchad, in Hebrew).

Piore, M.J. (1979) Birds of passage: migrant labor and industrial societies (Cambridge: Cambridge University Press).

Portes, A. and Rumbaut, R. (1996) Immigrant America: a portrait (Berkeley: University of California Press).

Raijman, R. and Kemp, A. (2004) Consuming the Holy Spirit in the holy land: evangelical churches, labor migrants, and the Jewish state, in: Y.S. Carmeli and K. Applbaum (eds), Consumption and market society in Israel, pp. 163-184 (Oxford: Berg).

Raijman, R. and Kemp, A. (2007) Labor migration, managing the ethno-national conflict, and client politics in Israel, in: S.S. Willen (ed), Transnational Migration to Israel in Global Comparative Context, pp. 31-50 (Plymouth: Lexington Books). 
Raijman, R., Schammah-Gesser, S. and Kemp, A. (2003) International migration, domestic work, and care work: undocumented Latina migrants in Israel, Gender \& Society, 17(5), pp. 727-749.

Raijman, R. and Semyonov, M. (2004) Perceived threat and exclusionary attitudes towards foreign workers in Israel, Ethnic and Racial Studies, 27(5), pp. 780-799.

Rebhun, U. and Malach, G. (2009) Demographic trends in Israel (Jerusalem: Merkaz Metzilah).

Resnik, J. (2009) Contextualizing recognition, absence of recognition, and misrecognition: the case of migrant workers' children in daycares in Israel, Journal of Curriculum Studies, 41(5), pp. 625649.

Rogers, R. (1985) Guests come to stay: the effects of European labor migration on sending and receiving countries (Boulder: Westview Press).

Rosenhek, Z. (2002) Migration regimes and social rights: migrant workers in the Israeli welfare state, in: D. Levy and Y. Weiss (eds), Challenging ethnic citizenship: German and Israeli perspectives on immigration, pp. 137-153 (Oxford: Berghahn).

Rouhana, N. (1997) Palestinian citizens in an ethnic Jewish state: identities in conflict (New Haven: Yale University Press).

Schain, Y. (2002) Jewish kinship at a crossroads: lessons for homelands and diasporas, Political Science Quarterly, 117(2), pp. 279-309.

Schölch, A. (1985) The demographic development of Palestine, 1850-1882, International Journal of Middle East Studies, 17(4), pp. 485-505.

Seeman, D. (2009) One People, One Blood: Ethiopian-Israelis and the Return to Judaism (Rutgers: Rutgers University Press).

Shachar, A. (2000) Citizenship and membership in the Israeli polity, in: D.B. Klusmeyer and T.A. Aleinikoff (eds), From migrants to citizens: membership in a changing world, pp. 386-433 (Washington, D.C.: Carnegie Endowment for International Peace).

Shafir, G. (1989) Land, labor, and the origins of the Israeli-Palestinian conflict, 1882-1914 (Cambridge: Cambridge University Press).

Shafir, G. and Peled, Y. (2002) Being Israeli: the dynamics of multiple citizenship (Cambridge: Cambridge University Press).

Sheleg, Y. (2004) Not Halakhically Jewish: the Dilemma of Non-Jewish Immigrants in Israel (Jerusalem: Israeli Democracy Institute, Working Paper 51, in Hebrew).

Sheleg, Y. (2009) Let the convert beware, HaAretz, 4 April.

Shuval, J. (1998) Migration to Israel: the mythology of 'uniqueness', International Migration, 36(1), pp. 3-24.

Shuval, J. and Leshem, E. (1998) The sociology of migration in Israel: a critical view, in: E. Leshem and J. Shuval (eds), Immigration to Israel: sociological perspectives, pp. 3-50 (London: Transaction Publishers).

Smooha, S. (1990) Minority status in an ethnic democracy: The status of the Arab minority in Israel, Ethnic and Racial Studies, 13(3), pp. 389-413.

Surak, K. (2008) Convergence in Foreigners' Rights and Citizenship Laws? A Look at Japan, International Migration Review, 42(3), pp. 550-575.

Swirsky, S. (1989) Israel: the Oriental majority (London: Zed Books). 
Wagaw, T.G. (1993) For our soul: Ethiopian Jews in Israel (Detroit: Wayne State University Press).

Walzer, M. (1983) Spheres of justice: a defense of pluralism and equality (New York: Basic Books).

Weil, S. (1996) Religion, Blood and the Equality of Rights The Case of Ethiopian Jews in Israel, International Journal on Minority and Group Rights, 4(3-4), pp. 397-412.

Weiler-Polak, D. (2009a) Netanyahu defers expulsion of children of migrant workers, HaAretz, 31 July.

Weiler-Polak, D. (2009b) Ignoring Arab women, ministry okays 3,000 new foreign workers, HaAretz, 22 October.

Willen, S.S. (2005) Birthing "invisible" children: State power, NGO activism, and reproductive health among illegal migrant workers in Tel Aviv, Israel, Journal of Middle East Women's Studies, $1(2)$, pp. 55-88.

Willen, S.S. (2007) Transnational Migration to Israel in Global Comparative Context (Plymouth: Lexington Books).

Wurgaft, N. (2006) Police! Open Up! Migrant Workers in Israel (Tel Aviv: Am Oved, in Hebrew).

Ya'ar, E. (2005) Continuity and Change in Israeli Society: The Test of the Melting Pot, Israel Studies, 10(2), pp. 91-128.

Yakobson, A. (2009) Despite the ultra-Orthodox, HaAretz, 8 July.

Yiftachel, O. and Ghanem, A. (2004) Learning from the Judaization of Israel/Palestine, in: E.P. Kaufmann (ed), Rethinking ethnicity: majority groups and dominant minorities, pp. 179-197 (London: Routledge).

Zolberg, A. (1987) Wanted but not welcome: alien labor in Western development, in: W. Alonso (ed), Population in an interacting world, pp. 36-73 (Cambridge, MA: Harvard University Press). 